\title{
KAUNO VIDUTINIO AMŽIAUS GYVENTOJŲ POŽIŪRIO I SAVO SVEIKATĄ SĄSAJOS SU FIZINIU AKTYVUMU IR SOCIALINIAIS-DEMOGRAFINIAIS VEIKSNIAIS
}

\author{
Edita Maciulevičienè, Kęstutis Kardelis \\ Lietuvos kūno kultūros akademija, Kaunas, Lietuva
}

\begin{abstract}
Edita Maciulevičienė. Edukologijos magistrè. Lietuvos kūno kultūros akademijos edukologijos krypties doktorantė. Mokslinių tyrimų kryptis - vidutinio amžiaus gyventojų fizinio aktyvumo laisvalaikiu sąsajos su socialiniais-demografiniais veiksniais
\end{abstract}

\section{SANTRAUKA}

Tyrimu siekta atskleisti Kauno miesto vidutinio amžiaus gyventoju požiūrio ì savo sveikata sqsajas su jufiziniu aktyvumu laisvalaikiu ir socialiniais-demografiniais veiksniais.

Tiriamaja imti sudare 916 tiriamuju (392 vyrai ir 524 moterys), atsitiktinès imties būdu parinktu ǐ̌ Kauno miesto gyventoju. Ju amžius - nuo 35 iki 64 metu. Taikytas apklausos raštu metodas, kuriuo buvo vertinamas gyventoju požiüris i savo sveikata ir fizinį aktyvuma laisvalaikiu kartu nustatant ju socialinius-demografinius ypatumus. Tyrimo duomenys apdoroti iprastiniais statistinés analizès metodais.

Tiriant Kauno miesto 35-64 metu gyventoju požiūri i savo sveikata nustatyta, kad labai gerai ir gerai savo sveikata vertino $25,1 \%$, vidutiniškai - 61,7\%, blogai ir labai blogai - 13,2\% apklaustuju. Vyrai subjektyviai savo sveikata kaip gerq ir labai gerq vertino dažniau nei moterys $(29,8 \%$ ir 21,4\%, p < 0,01). Požiūrio í fizinį aktyvuma, ¿̇vertinta pagal fiziniu pratimu kultivavimo dažnị laisvalaikiu, duomenimis, fiziškai aktyvūs 23,8\% tiriamuju. Likusieji priskirti nepakankamai fiziškai aktyviu asmenu grupei. Lyginamoji tyrimo duomenu analizè atskleidè subjektyvaus sveikatos vertinimo priklausomumq nuo tirtuju išsimokslinimo ir ju socialinès padèties: žemesnio išsimokslinimo bei socialinès padèties gyventojai savo sveikata linke vertinti 2,6 karto blogiau. Didejant amžiui, subjektyvus savo sveikatos vertinimas blogèjo: 35-44 m. amžiaus grupèje blogai ir labai blogai savo sveikata vertino 6,3\%, 45-54 m. - 11,6\%, 55-64 m. - 19,6\% tiriamuju ( $p<0,05)$.

Vienmatès analizès duomenimis, blogesnis subjektyvus sveikatos vertinimas taip pat buvo susijęs su nepakankamu fiziniu aktyvumu. Logistinè regresine analizè atskleidè statistiškai reikšmingq tikimybę, kad subjektyviai savo sveikata blogiau vertins vyresnio amžiaus, nepakankamo fizinio aktyvumo, žemesnio socialinio statuso gyventojai, taip pat moterys, lyginant jas su vyrais.

Raktažodžiai: požiūris ì savo sveikata, fizinis aktyvumas, socialiniai-demografiniai veiksniai.

\section{IVADAS}

$\mathrm{P}$ sichologinè sveikatos apibrèžimo koncepcija teigia, kad svarbiausia, kaip savo sveikatą interpretuoja pats individas (Kalédienè ir kt., 1999). Subjektyvus sveikatos vertinimas yra daugiareikšmè sąvoka, turinti sąsajų su asmens sveikatos būkle ir ją lemiančiais veiksniais (Rèklaitienè ir kt., 2004). Pastarieji gali daryti itaką teigiamam arba neigiamam asmens požiūriui į savo sveikatą. Savo ruožtu požiūris i savo sveikatą ir jos vertinimas, būdamas tarpiniu kintamuoju tarp objektyvių sveikatos problemų ir subjektyviai ivertintos gyvenimo kokybės, gali lemti asmens nusiteikimą naudotis sveikatos priežiūros paslaugomis. Pavyzdžiui, nurodoma, kad nepalankiai savo sveikatą vertinantis asmuo yra pasirengęs vartoti vaistus, laikytis nurodyto sveikatos priežiūros režimo (Aadahl et al., 2007). 
Kita vertus, nors požiūris į savo sveikatą yra subjektyvus, tačiau moksliniai tyrimai ir gydomoji praktika patvirtina, kad jis rodo ne tik fizinę, emocinę asmens būklę, bet ir savijautą, daugelị kitų psichofiziologinių reiškiniu (Goštautas, 1999). Jis taip pat leidžia prognozuoti asmens sveikatos būklę. Antai, taikant daugiamatès logistinès regresijos modelị, nustatytos lètinių neinfekcinių ligu rizikos veiksnių sąsajos su subjektyviu savo sveikatos vertinimu: vyrų nutukimas ir nepakankamas fizinis aktyvumas, o moteru arterinè hipertenzija ir nutukimas susiję su blogesniu savo sveikatos vertinimu (Armonaite, 2006). Yra duomenų, rodančių, kad neigiamas požiūris į savo sveikatą gali būti susijęs su trumpesniu gyvenimu, ankstyva mirtimi, o prašymas įvertinti savo sveikatą yra tolygus subjektyviam gyvenimo trukmès ivvertinimui (Goštautas ir kt., 1994). Subjektyvus savo sveikatos vertinimas, analizuojant sveikatos programų veiksmingumą visuomenèje, teikia daugiau informacijos, negu sergamumo ir mirštamumo statistika (Rohrer, 2004).

Išsakyti teiginiai leidžia daryti išvadą, kad visose sveikatos priežiūros grandyse svarbu keisti žmoniu požiūri i i savo sveikatą. Tokio požiūrio pasikeitimui lemiamos itakos gali tureti įvairiu sveikatos rizikos veiksnių mažinimas. Antra vertus, taikant sveikatos rizikos veiksniu paplitima mažinančias profilaktinio pobūdžio programas, svarbu atsižvelgti i veiksnius, galinčius daryti ittaką asmens požiūriui i savo sveikatą. Tokių veiksniu nustatymas visu pirma svarbus lètiniu neinfekcinių ligų profilaktikai, nes taikant ịvairias profilaktinio poveikio programas svarbu atsižvelgti ne tik į rizikos veiksnių paplitimą, bet ir į kitus asmens ypatumus, galinčius padidinti arba sumažinti poveikio priemonių veiksmingumą. Tokiais ypatumais galètų būti socialiniai-demografiniai veiksniai. Jų, kaip ir kito sveikatos rizikos veiksnio - nepakankamo fizinio aktyvumo sąsajų su asmens požiūriu i savo sveikatą atskleidimas šio tyrimo objektas.

Planuodami tyrimą rèmėmès pirmine prielaida, kad požiūris ị savo sveikatą priklauso ne tik nuo asmeniui būdingu sveikatos rizikos veiksniu (šiuo atveju nuo fizinio aktyvumo laisvalaikiu), bet ir nuo socialinių-demografinių. Tarp pastaruju prognozavome amžiaus, lyties, išsimokslinimo ir socialinio statuso svarbą.

Tyrimo tikslas - atskleisti Kauno miesto vidutinio amžiaus gyventojų požiūrio į savo sveikatą sąsajas su laisvalaikio fiziniu aktyvumu ir socialiniais-demografiniais veiksniais.

\section{TYRIMO METODIKA}

Tiriamieji. Tiriamają imti sudare 916 atsitiktinai parinktu Kauno miesto $35-64 \mathrm{~m}$. gyventoju (392 vyrai ir 524 moterys). Visi tiriamieji buvo suskirstyti $\mathfrak{i}$ tris amžiaus grupes. Pirmą grupę $(n=238)$, i kurią pateko 146 moterys ir 92 vyrai, sudare $35-44 \mathrm{~m}$. asmenys. Antros grupès $(\mathrm{n}=321)$ tiriamuju amžius - nuo 45 iki $54 \mathrm{~m}$. (181 moteris ir 140 vyru), o trečios tiriamieji $(\mathrm{n}=336)-55-64 \mathrm{~m}$. amžiaus (176 moterys ir 160 vyru).

Tyrimo metodas. Tyrimo metu taikytas mūsu parengtas apklausos raštu metodas. Klausimyną sudare 16 klausimų, padejusių atskleisti tiriamujų požiūrị i savo sveikatą ir fizini aktyvumą laisvalaikiu, ivertinti jų socialinius-demografinius ypatumus. Tiriamujų požiūris į savo sveikatą nustatytas pagal tai, kaip jie subjektyviai vertina savo sveikatą. Ją vertinant buvo pateikti tokie atsakymų variantai: 1 - labai gera, 2 - gera, 3 - vidutine, 4 - bloga, 5 - labai bloga sveikata. Fizinis aktyvumas vertintas pagal dažni nurodant, kiek kartu asmuo per savaitę yra fiziškai aktyvus (fiziškai aktyvių grupę sudarè asmenys, apklausos metu nurodę, kad laisvalaikiu kasdien, $4-6$ arba $2-3$ kartus per savaitę, mankštinasi mažiausiai 30 minučių taip, kad suprakaituotų ir padažnètų kvėpavimas, o fiziškai pasyvių grupę sudarè tiriamieji, kurie tai darè kartą per savaitę, mènesi ar dar rečiau).

Tyrimo procedūros. Gyventojų apklausa buvo vykdoma lankantis jų namuose, iš anksto aptarus vizita. Apklausos metu tiriamiesiems žodžiu buvo pateikiami anketos klausimai, atsakymus i kuriuos pildè apklausos vedejjas. Vykdant apklausą buvo vadovaujamasi etiniais ir teisiniais tyrimo principais. Visi tyrimo dalyviai buvo informuoti apie tyrimo tikslą, duomenų anonimiškumą. Buvo pabrèžiama, kad dalyvavimas tyrime nèra privalomas. Tiriamuju buvo paprašyta atsakyti i pateiktus klausimus sąžiningai.

Statistinė analizè. Susisteminant ir apdorojant tyrimo duomenis buvo naudojama duomenu bazių valdymo sistema SPSS 12.0 for WINDOWS. Statistiniam tyrimo duomenu patikimumui ivertinti taikytas Pirsono chi kvadrato $\left(\chi^{2}\right)$ kriterijus. Statistiškai patikimais laikyti tie atvejai, kai $p<0,05$. Ryšys tarp subjektyvaus sveikatos vertinimo ir socialinių-demografinių veiksnių bei fizinio aktyvumo laisvalaikiu įvertintas šansų (galimybių) santykiu ( ̌́S) taikant binarinę daugiaveiksmę logistinę regresiją. Sudarant pasikliautinaji intervalą (PI), pasirinktas 95\% pasikliautinumo lygmuo. 


\section{REZULTATAI}

Tiriant Kauno miesto 35-64 m. gyventoju požiūrị i savo sveikatą nustatyta, kad labai gerai ir gerai savo sveikatą vertino $25,1 \%$, vidutiniškai $61,7 \%$, blogai ir labai blogai - 13,2\% tiriamujų. Vyrų ir moteru subjektyvus savo sveikatos vertinimas skyrèsi statistiškai reikšmingai (1 pav.).

Moterų, savo sveikatą vertinusių labai gerai ir gerai, buvo mažiau nei vyrų (atitinkamai 21,4 ir $29,8 \% ; \mathrm{p}<0,01)$, vyrai rečiau savo sveikatą vertino kaip vidutinišką $(57,7$ ir $65,0 \% ; \mathrm{p}<0,05)$. Labai blogai ir blogai savo sveikatą vertino 13,6\% moteru ir $12,5 \%$ vyru.

Tiriant gyventojų požiūrị i jų fizini aktyvumą, ivvertintą pagal fiziniu pratimų kultivavimo dažnį laisvalaikiu, nustatyta, kad fiziškai aktyvūs $23,8 \%$ visu apklaustujų. Lyginant duomenis amžiaus požiūriu pastebèta, kad fiziškai pasyvesni jauniausios tiriamujų grupès $(35-44 \mathrm{~m}$.) respondentai, lyginant juos su kitomis amžiaus grupèmis $(p<0,001)$. Fiziškai aktyviausia laisvalaikiu 55-64 m. amžiaus gyventojų grupė (42,7\%). Kiek mažiau aktyvūs $45-54 \mathrm{~m}$. tiriamieji $(40,4 \%)$, mažiausiai aktyvūs - 35-44 m. asmenys (16,9\%). Pagal fizinio aktyvumo laisvalaikiu dažni vyrai
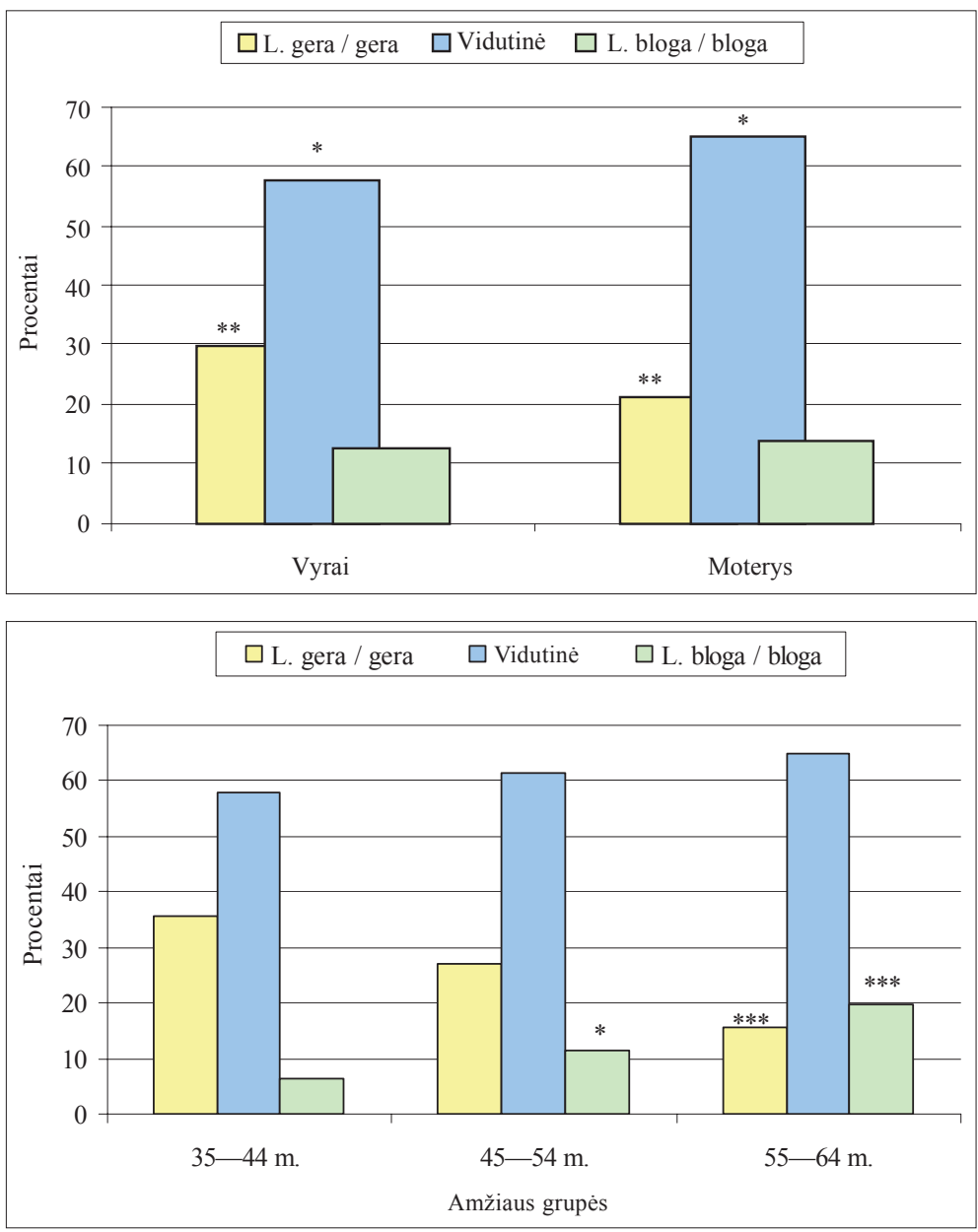

fiziškai aktyvesni, lyginant su moterų aktyvumu (atitinkamai 58,0 ir 42, 0\%; $\mathrm{p}<0,01$ ).

Požiūrio i̇ savo sveikatą duomenis lyginome su tiriamujų amžiumi, požiūriu ị fizinị aktyvumą laisvalaikiu, socialine padètimi ir išsimokslinimu (šios analizès metu vyrų ir moterų duomenys buvo sujungti).

Lyginamosios analizès duomenimis, skirtingu amžiaus grupių tiriamieji nevienodai vertino savo sveikatą (2 pav.).

Antrame paveiksle pateikti duomenys rodo, kad 35-44 m. tiriamieji savo sveikatą vertino kur kas geriau negu 55-64 m. amžiaus gyventojai (savo sveikatą vertino kaip labai gerą ir gerą atitinkamai 35,7\% pirmujų ir 15,5\% antrujų; $\mathrm{p}<0,001$ ). Mažesnis skirtumas tarp grupiu pastebètas tiriamiesiems vertinant savo sveikatą kaip vidutinę. Tuo tarpu vertinančių savo sveikatą kaip bloga ir labai blogą vyriausioje amžiaus grupejje buvo $19,6 \%$, jauniausioje - tik $6,3 \%(\mathrm{p}<0,001)$. Blogiau savo sveikata, lyginant su $35-44 \mathrm{~m}$. amžiaus grupe, vertino ir $45-54 \mathrm{~m}$. tiriamieji.

Taip pat aptiktas skirtumas, lyginant subjektyvaus sveikatos vertinimo duomenis su socialine tirtuju padètimi (3 pav.).

1 pav. Tirtų gyventojų subjektyvaus savo sveikatos vertinimo raiška lyties grupèse

Pastaba. * - $\mathrm{p}<0,05 ; * *-\mathrm{p}<0,01$, lyginant vyrus ir moteris.

2 pav. Subjektyvaus sveikatos vertinimo raiška tiriamųjų grupèse pagal amžių

Pastaba. * - $\mathrm{p}<0,05 ; * * *-\mathrm{p}<0,001$, lyginant $\mathrm{su}$ jauniausia amžiaus grupe. 
3 pav. Subjektyvaus sveikatos vertinimo duomenų palyginimas su tirtụjų socialine padètimi
Pastaba. $* * *-p<0,001$, lyginant su pensininku, bedarbiu, invalidu grupe.

4 pav. Subjektyvaus sveikatos vertinimo ir fizinio aktyvumo laisvalaikiu palyginimas
Pastaba. * - p $<0,05$, lyginant su fiziškai aktyviais kasdien arba 4-6 kartus per savaitę;

$* * *-p<0,001$, lyginant su fiziškai aktyviais $2-3$ kartus per savaitę.
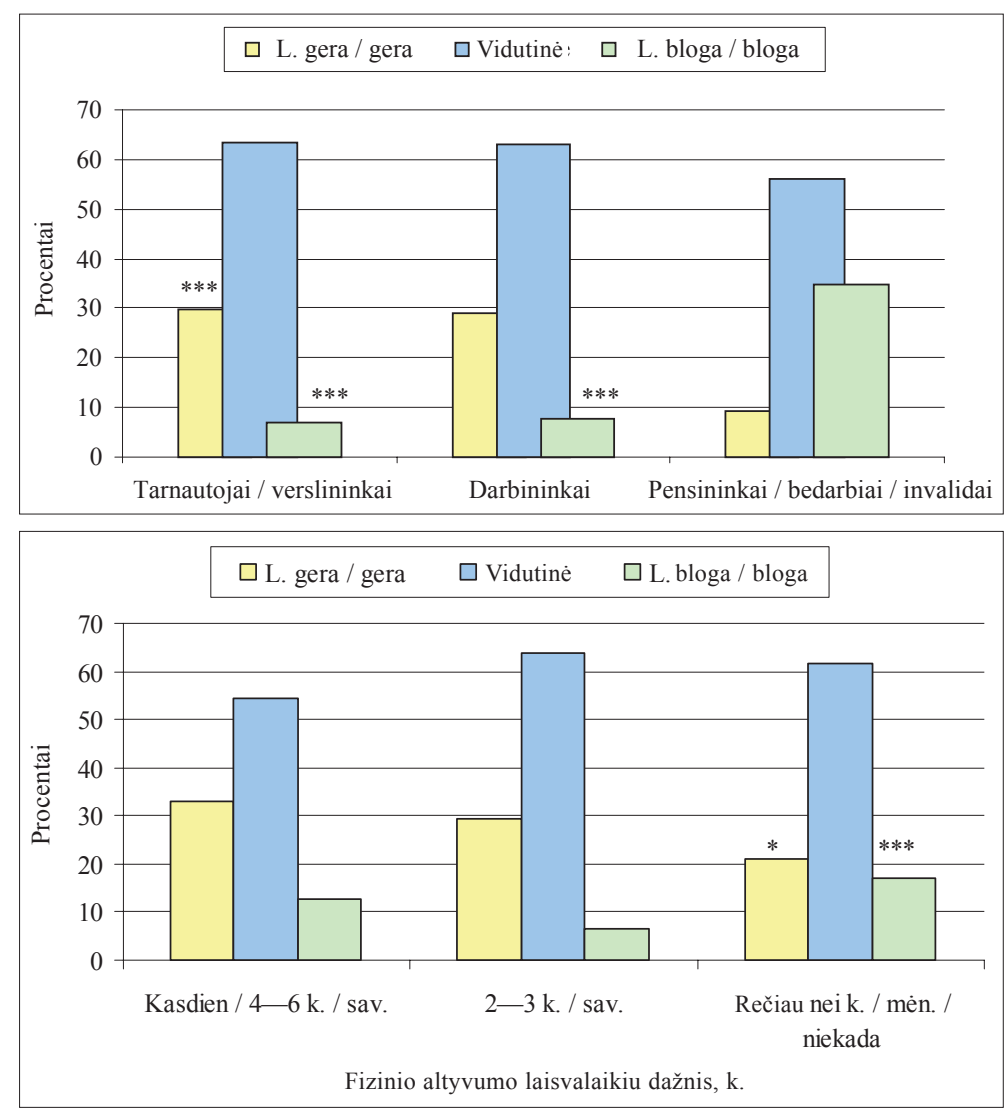

Iš 3 paveiksle pateiktų duomenu matyti, kad tarnautojų ir verslininkų, vertinusių savo sveikatą kaip gera ir labai gera, buvo daugiau nei pensininku, bedarbiu bei invalidu (atitinkamai 29,9 ir $9,3 \% ; p<0,001)$. Darbininku grupeje gerai ir labai gerai savo sveikatą vertino toks pat procentas tiriamuju kaip ir verslininkų bei tarnautojų. Blogiausiai savo sveikatą vertino pensininkai, bedarbiai ir invalidai, lyginant juos su darbininku, verslininku ir tarnautojų grupemis (atitinkamai 34,7 ir 7,7\%; $\mathrm{p}<0,001$ ir 34,7 ir $6,8 \%$; $<0,001)$.

Tyrimo duomenys patvirtino literatūroje nurodomą fizinio aktyvumo laisvalaikiu reikšmę subjektyviam sveikatos vertinimui. Subjektyvaus sveikatos vertinimo ir fizinio aktyvumo laisvalaikiu dažnio sąsają rodo 4 paveiksle pateikti duomenys.

Iš šių duomenų matyti, kad kuo didesnis fizinio aktyvumo dažnis laisvalaikiu, tuo asmuo savo sveikatą linkęs vertinti geriau. Tiriamieji, laisvalaikiu fiziškai aktyvūs kasdien ar 4-6 kartus per savaitę, savo sveikatą kaip gerą ir labai gerą vertino dažniau negu nurodžiusieji, kad fiziškai aktyvūs yra rečiau nei kartą per mènesi arba apskritai neaktyvūs (atitinkamai 33 ir 21,1\%; $<<0,05)$. Pastebèta tendencija, kad tie vidutinio amžiaus gyventojai, kurie laisvalaikiu mankštinasi 2-3 kartus per savaitę, dažniau nurodè, kad jų sveikata yra gera ar labai gera $(29,5 \%)$, palyginti su nepakankamai fiziškai aktyviais $(21,1 \%)$. Blogiausiai savo sveikatą vertino nepakankamai fiziškai aktyvūs tiriamieji, t. y. nurodžiusieji, kad laisvalaikiu mankštinasi rečiau nei kartą per mènesi arba apskritai nesimankština (17,0\%), lyginant juos su besimankštinančiais kasdien arba 4-6 kartus per savaite $(12,8 \%)$ ir su tais, kurie tai daro 2-3 kartus per savaitę $(6,6 \% ; p<0,001)$.

Statistiškai reikšmingas ryšys pastebėtas ir tarp tiriamujų išsimokslinimo bei jų požiūrio i savo sveikatą, nustatyto pagal subjektyvų savo sveikatos vertinima (1 lent.).

Iš pirmoje lentelejje pateiktų duomenų matyti, kad aukštojo ar aukštesniojo išsimokslinimo tiriamieji savo sveikatą subjektyviai vertino geriau nei turintys nebaigtą vidurini ar pradini išsimokslinimą. Panašus procentas tiriamujų savo sveikatą vertino kaip vidutinišką, nors kiek mažiau tokiu buvo pradinio išsimokslinimo grupeje. Lyginamoji subjektyvaus savo sveikatos vertinimo ir išsimokslinimo duomenų analizè parodè, kad kuo žemesnis gyventojų išsimokslinimas, tuo blogiau jie vertina savo sveikatą.

Remiantis logistinès regresinès analizès duomenimis, nustatytas statistiškai reikšmingas tirtu asmenų subjektyvaus savo sveikatos vertinimo ryšys su jų požiūriu i fizini aktyvumą laisvalaikiu ir tokiais nepriklausomais tyrimo kintamaisiais kaip amžius, lytis, socialinè padètis bei išsimokslinimas (2 lent.).

Iš antroje lentelejje pateiktų duomenų matyti tokia tikimybè: laisvalaikiu nesimankštinantys vi- 


\begin{tabular}{|l|c|c|c|c|c|c|}
\hline \multirow{2}{*}{ Išsimokslinimas } & \multicolumn{6}{|c|}{ Subjektyvus sveikatos vertinimas } \\
& \multicolumn{2}{|c|}{ Labai gera ir gera } & \multicolumn{2}{c|}{ Vidutine } & \multicolumn{2}{c|}{ Bloga ir labai bloga } \\
\cline { 2 - 7 } & $\mathbf{n}$ & $\mathbf{\%}$ & $\mathbf{n}$ & $\mathbf{\%}$ & $\mathbf{n}$ & \% \\
\hline Aukštasis & 76 & 29,2 & 163 & 62,7 & 21 & 8,1 \\
\hline Aukštesnysis & 76 & 26,5 & 179 & 62,4 & 32 & 11,1 \\
\hline Vidurinis & 64 & 23,5 & 166 & 61,0 & 42 & $15,4^{*}$ \\
\hline Nebaigtas vidurinis & 7 & $11,5 * *$ & 37 & 60,7 & 17 & $27,9 * * *$ \\
\hline Pradinis & 1 & 7,7 & 7 & 53,8 & 5 & 38,5 \\
\hline
\end{tabular}

1 lentelè. Subjektyvus sveikatos vertinimas išsimokslinimo grupèse

\begin{tabular}{|l|c|}
\hline \multicolumn{1}{|c|}{ Analizuojami požymiai } & $\begin{array}{c}\text { Vidutiné / bloga / labai bloga sveikata } \\
\text { SS (95\% PI) }\end{array}$ \\
\hline $\begin{array}{l}\text { Fizinio aktyvumo laisvalaikiu dažnis } \\
\text { Kasdien / 4-6 k. / sav. / 2-3 k. / sav. / 1 k. / sav. } \\
\text { Rečiau nei k. / mèn. / niekada }\end{array}$ & 1 \\
\hline $\begin{array}{l}\text { Socialinè padėtis } \\
\text { Tarnautojas / verslininkas / darbininkas } \\
\text { Pensininkas / nedirbantis / invalidas }\end{array}$ & $1,522(1,097-2,111)^{*}$ \\
\hline $\begin{array}{l}\text { Išsimokslinimas } \\
\text { Aukštasis / aukštesnysis / vidurinis / nebaigtas } \\
\text { vidurinis }\end{array}$ & 1 \\
Pradinis & $2,666(1,546-4,596)^{* * *}$ \\
\hline $\begin{array}{l}\text { Lytis } \\
\text { Vyras }\end{array}$ & 1 \\
Moteris & $1,428(0,636-3,206)$ \\
\hline $\begin{array}{l}\text { Amžius } \\
\text { Nuo 35 iki } 54 \mathrm{~m} .\end{array}$ & $1,666(1,202-2,308)^{*}$ \\
Nuo 55 iki $64 \mathrm{~m}$. & 1 \\
\hline
\end{tabular}

Pastaba. $*-\mathrm{p}<0,05, * *-\mathrm{p}<0,01$ $* * *-\mathrm{p}<0,001$, lyginant su aukštojo išsimokslinimo tiriamaisiais.

2 lentelè. Vidutinio, blogo ir labai blogo subjektyvaus savo sveikatos vertinimo galimybès ir požiūrio ị fizinị aktyvumą bei socialinių-demografinių veiksnių sąsajos

Pastaba. * — šansų santykis statistiškai reikšmingas $(\mathrm{p}<0,05) ; * * *$ _ šansų santykis statistiškai reikšmingas $(\mathrm{p}<0,001)$; ŠS $(95 \%$ PI) - šansu santykis (95\% pasikliautinasis intervalas). dutinio amžiaus gyventojai savo sveikatą vertins 1,5 karto blogiau už tuos, kurie yra fiziškai aktyvūs. Labiausiai išreikšta tikimybė savo sveikatą vertinti kaip bloga ir labai bloga nustatyta socialinès padèties požiūriu: žemesnès socialinès padèties asmenys savo sveikatą subjektyviai linkę vertinti net 2,7 karto blogiau už tuos, kurių socialinè padėtis yra aukštesnè. Ryški negatyvaus savo sveikatos vertinimo tikimybė amžiaus ir lyties aspektu (pastaroji prognozuoja mažiau teigiamą moterų nei vyru subjektyvų savo sveikatos vertinimą). Pastebima tendencija, kad žemesnio išsimokslinimo asmenys subjektyviai savo sveikatą gali vertinti blogiau nei turintys aukštesnị išsimokslinimą.

\section{REZULTATUQ APTARIMAS}

Analizuodami Kauno miesto vidutinio amžiaus gyventojų požiūrio ị savo sveikatą duomenis pastebejjome, kad vyrų, ivertinusių savo sveikatą kaip gerą ir labai gera, lyginant su moterimis, buvo daugiau. Šiuos duomenis patvirtina ir kitų autorių atlikti tyrimai, kuriais pripažistama, kad moterys subjektyviai savo sveikatą vertina blogiau nei vyrai (Rèklaitienė ir kt., 2004). Didžiausias vyru ir moteru subjektyvaus sveikatos vertinimo skirtumas nustatytas 45-54 m. amžiaus grupeje, o jaunesnio amžiaus tiriamiesiems šis skirtumas mažiau reikšmingas. Požiūrio ị savo sveikatą skirtumas ly- ties grupèse siejamas su menopauzès sukeliamais pokyčiais moters organizme ir su tuo susijusiomis emocinemis bei fizinèmis problemomis (Outram et al., 2004). Moterys daugiau serga lètinèmis ligomis, stipresnè jų organizmo reakcija i stresą, kuris vèliau pasireiškia depresija, o vyrai dažniau serga ūminèmis ligomis, neretai besibaigiančiomis mirtimi (Leinonen et al., 1998). Literatūros duomenimis, rūkymas, nutukimas, nepakankamas moteru fizinis aktyvumas lemia 10 kartų didesnę blogos jų sveikatos tikimybę (Meurer et al., 2001).

Kitų tyrejuc duomenimis, rizikos veiksniai ir elgsenos ypatybès nėra pagrindiniai, galintys lemti asmens požiūrị i savo sveikatą. Kur kas dažniau šiam požiūriui ịtakos gali turèti tiriamojo sveikatos būklè, funkcinis jo organizmo pajėgumas. Be to, manoma, kad iš asmens požiūrio i savo sveikatą, parodančio jo subjektyvų savo sveikatos vertinimą, galima spręsti apie to asmens gyvenimo kokybę (Armonaitè, 2006).

Tyrimo duomenys rodo, kad vyresnio amžiaus (55-64 m.) gyventojai savo sveikatą vertino daug blogiau nei jaunesnio amžiaus (34-45 m.) asmenys. Skirtingam sveikatos vertinimui neabejotinos reikšmès galëjo turèti objektyviai blogesnè vyresnių žmonių sveikata.

Fizinis aktyvumas yra pagrindinis veiksnys, lemiantis daugelio lètinių ligu (širdies, diabeto, storosios žarnos vėžio ir padidèjusio kraujospūdžio) 
vystymąsi, ypač tarp vyresnio amžiaus žmoniu (NCEP, 2002). Tyrimai parodè, kad ilgesni laiką reguliariai atliekama individuali mankšta palaiko mažai fiziškai aktyvių vyresnio amžiaus moteru fizini pajègumą ir pagerina subjektyvų sveikatos vertinimą (Gaigalienè, 2001).

Gyventojų socialinès padèties ir subjektyvaus savo sveikatos vertinimo logistinès regresinès analizès duomenys leidžia teigti, kad aukštesnès socialinès padėties vidutinio amžiaus gyventojai subjektyviai savo sveikatą vertina geriau, o žemesnès socialinès padèties tiriamieji savo sveikatą linkę vertinti net 2,7 karto blogiau. Šio tyrimo duomenimis, savo sveikatą vertino subjektyviai blogai ir labai blogai 6,8\% verslininku ir tarnautojų, o tarp pensininkų, bedarbių ir invalidų ją blogai ir labai blogai ivertino 34,7\% ( $<0,001)$.

Lyginant subjektyvaus sveikatos vertinimo ir išsimokslinimo duomenis galima pastebèti tendenciją, kad kuo žemesnis gyventojų išsimokslinimas, tuo blogiau jie vertina savo sveikatą. Užimama aukštesnè socialinè ir ekonominè padètis (aukštesnis išsimokslinimas ir geriau apmokamas darbas) yra susiję su labiau teigiamu savo sveikatos vertinimu. Ši sąsaja gali būti paaiškinama taip: aukštesnio išsimokslinimo asmenys paprastai turi daugiau žinių apie sveiką gyvenseną (fizini aktyvumą, mitybą, apie rūkymo ir svaigiuju gèrimu žalą sveikatai), o didesnès pajamos leidžia geriau rūpintis savo sveikata, t. y. rinktis ịvairesni maistą, vartoti daugiau šviežių vaisių ir daržovių, sportuoti (Nilsson, Orth-Gomer, 2000). Subjektyvaus savo sveikatos vertinimo bei psichosocialinių veiksniu sąsajas nustatė ir kiti tyrèjai pastebėdami, kad palankiau savo sveikatą vertina fiziškai aktyvūs, geros psichinès-emocinès būsenos, mažiau nusiskundimų turintys bei geresnès socialinès-ekonominès padèties asmenys (Astrom, Rise, 2001).

Tyrimo duomenys patvirtina literatūroje nurodomą fizinio aktyvumo laisvalaikiu naudą ir reikšmę gyventojų požiūriui ị savo sveikatą. Tiriamieji, kurie mankštinosi kasdien ar 4-6 kartus per savaitę laisvalaikiu mažiausiai 30 minučių taip, kad suprakaituotų ir padažnètų kvėpavimas, savo sveikatą kaip gerą ir labai gerą vertino dažniau nei besimankštinantys rečiau nei kartą per mėnesi ar apskritai nesimankštinantys. Logistinès regresinès analizès rezultatai patvirtina fizinio aktyvumo sąsa- ją su požiūriu į savo sveikatą. Nustatyta statistiškai reikšminga tikimybè, kad laisvalaikiu nesimankštinantys vidutinio amžiaus gyventojai savo sveikatą linkę vertinti 1,5 karto blogiau už tuos, kurie yra fiziškai aktyvūs. Yra žinoma, kad reguliarus fizinis aktyvumas padeda palaikyti optimalų svori, kurio, kaip vieno iš širdies ir kraujagyslių sistemos ligų rizikos veiksnio, sumažinimas padeda veiksmingai koreguoti kraujo spaudimą (Kahn et al., 2002).

Lietuvoje atliktų tyrimų duomenimis (Gaigalienè, 1998), pagyvenę asmenys mažai mankštinasi ir nenoriai dirba fizini darbą. Juos mažiau domina grupinè kūno kultūra. Nors jie mieliau mankštintųsi individualiai namie, tačiau stokoja mankštos pratimu kompleksų aprašymų ir kitos metodinès medžiagos. Kitų tyrëjų, kaip ir mūsų atlikto tyrimo, duomenys rodo, kad negatyvus savo sveikatos vertinimas yra susijęs ne tik su daugeliu socialinių-demografiniu veiksnių, bet ir su fiziniu aktyvumu (Rèklaitienè ir kt., 2004). Suprantama, kad pagrindinis demesys stiprinant žmonių sveikatą turètų būti nukreiptas i sveikatos mokymą per įvairias sveikatinimo programas, akcentuojant fizinio aktyvumo svarbą.

\section{IŠVADOS}

1. Kauno miesto vidutinio amžiaus gyventojų požiūrio i̇ savo sveikatą, nustatyto pagal subjektyvų savo sveikatos vertinima, tyrimo duomenimis, dauguma $(61,7 \%)$ šio amžiaus gyventoju savo sveikatą linkę vertinti kaip vidutinę ir tik ketvirtadalis mano, kad jų sveikata yra labai gera ar gera.

2. Požiūrio i fizini aktyvumą, nustatyto pagal mankštinimosi laisvalaikiu dažni, tyrimas atskleidè, kad fiziškai aktyvių tarp Kauno miesto 35-64 m. amžiaus gyventojų buvo $23,8 \%$.

3. Sugretinus požiūrio ị savo sveikatą ir fizinį aktyvumą duomenis nustatyta statistiškai reikšminga šių kintamujų sąsaja, t. y. kuo dažniau asmuo laisvalaikiu yra fiziškai aktyvus, tuo jis savo sveikatą subjektyviai linkęs vertinti geriau.

4. Požiūrio į savo sveikatą ir fizinį aktyvumą duomenų palyginimas socialinių-demografinių kintamuju grupèse atskleide, kad blogiau savo sveikatą linkę vertinti žemesnès socialinès padèties, vyresnio amžiaus asmenys ir moterys.

\section{LITERATŪRA}

Aadahl, M., Kjer, M., Jurgensen, T. (2007). Perceived exertion of physical activity: Negative association with self-rated fitness. Scandinavian Journal of Public Health, 35 (4), 403-409.
Armonaitè, R. (2006). Lètiniu neinfekciniu ligu rizikos veiksniu kontrolès gerinimo galimybès šeimos gydytojo aptarnaujamoje miesto bendruomeneje: daktaro disertacija. Kaunas: KMU. 
Astrom, A. N., Rise, J. (2001). Socio-economic differences in patterns of health and oral health behaviour in 25 year old Norwegians. Clinical Oral Investigations, 5 (2), $122-128$.

Gaigalienè, B. (2001). Mankštos reikšmè mažai fiziškai aktyvioms pagyvenusioms moterims. Gerontologija, 2 (2), $87-94$.

Gaigalienè, B. (1998). Mankštos reikšmė vyresnio amžiaus moteru fiziniam pajègumui ir subjektyviam sveikatos vertinimui. Medicina, 34, 1248-1256.

Goštautas, A. (1999). Interrelationship between Psychological Behaviour and Somatic Ischemic Heart Disease Risk Factors in Kaunas MONICA. Psychological Study. World Health Organization Report ICPICVD 118. Lugano. P. 5-27.

Goštautas, A., Tamošiūnas, A., Domarkienè, S. (1994). Mirusiujų ir išgyvenusių tarptautinès programos „Monika“ dalyviu savo sveikatos vertinimo ypatumai. Medicina, 30, $622-627$.

Kahn, E. B., Ramsey, L. T., Brownson, R. et al. (2002). Task Force on Community Preventive Services. The effectiveness of interventions to increase physical activity in hypertension patients. American Journal of Preventive Medicine, 22 (4S), 73-107.

Kaledienè, R., Petrauskienè, J., Rimpela, A. (1999). Šiuolaiki- nio visuomenès sveikatos mokslo teorija ir praktika. Vilnius.

Leinonen, R., Heikkinen, E., Jylha, M. (1998). Self-rated health and self-assessed change in health in elderly men and women in a five year longitudinal study. Social Science \& Medicine, 46, 591-597.

Meurer, L. N., Layde, P. M., Guse, C. E. (2001). Self-rated health status: A new vital sign for primary care? Wisconsin Medical Journal, 100, 35-39.

Nilsson, P., Orth-Gomer, K. (2000). Self-rated Health in a European Perspective. Stockholm.

Outram, S., Mishra, G. D., Schofield, M. J. (2004). Sociodemographic and health related factors associated with poor mental health in midlife Australian women. Women Health, $39,97-115$.

Rèklaitienè, R., Kazlauskaitè, M., Tamošiūnas, A. ir kt. (2004). Kauno vidutinio amžiaus gyventoju subjektyvus sveikatos vertinimas ir mirties tikimybe (20-ties metu stebejjimo duomenys). Medicina, 40, 807-815.

Rohrer, J. E. (2004). Medical care usage and self-rated mental health. BMC Public Health, 4:3.

Third Report of the National Cholesterol Education Program (NCEP) expert panel on detection, evaluation and treatment of high blood cholesterol in adults (Adult Treatment Panel III) final report. (2002). Circulation, 106, 3143.

\title{
INTERFACE BETWEEN KAUNAS MIDDLE-AGED PEOPLE'S SUBJECTIVE HEALTH SELF-ASSESSMENT, PHYSICAL ACTIVITY AND SOCIO-DEMOGRAPHIC FACTORS
}

\author{
Edita Maciulevičienè, Kęstutis Kardelis \\ Lithuanian Academy of Physical Education, Kaunas, Lithuania
}

\begin{abstract}
The aim of the research was to reveal the interface between Kaunas middle-aged people's attitude towards their health, leisure-time physical activity and socio-demographic factors.

Exploratory sample included 916 respondents (392 men and 524 women) who were selected randomly from Kaunas citizens. Respondents aged 35-64 years took part in the research. The interview method was applied to assess the respondents' attitude towards their health and leisure-time physical activity, in addition, their sociodemographic characteristics were determined. Conventional statistical methods were applied to process the data of the research.

The research data of the attitudes of Kaunas citizens aged 35-64 years towards their health revealed that $25.1 \%$ of the respondents thought that they were in good and very good health, $61.7 \%$ reported that they were in fair health and $13.2 \%$ assessed it as poor or very poor. Compared with males, females were less likely to assess their health as good or very good $(29.8 \%$ and $21.4 \%, \mathrm{p}<0.01)$. The data of the attitudes towards physical activity, assessed in terms of frequency of physical activity during leisure time, revealed that $23.8 \%$ the respondents were physically active, whereas others were insufficiently active. The comparative analysis of the data showed correlation between subjective health self-assessment, education and social status of the respondents: people from lower social classes and less educated respondents evaluated their health 2.6 times worse. Subjective health self-assessment became worse with increasing age: from $6.3 \%$ of the respondents aged $35-44$ years, $11.6 \%$ of people aged $45-54$ years to $19.6 \%(\mathrm{p}<0.05)$ aged $55-64$ years thought they were in poor and very poor health. One-dimensional data analysis revealed correlation between worse subjective health self-assessment and insufficient physical activity.

Logistic regression analysis revealed statistically significant possibility that people from lower social classes, those who are insufficiently active during their leisure time, and the older ones will be more likely to assess their health worse and, as well as women compared with men.
\end{abstract}

Keywords: subjective health self-assessment, physical activity, socio-demographic factors.

Gauta 2008 m. lapkričio 25 d.

Received on November 25, 2008

Priimta 2009 m. sausio 29 d.

Accepted on January 29, 2009
Edita Maciulevičienè

Lietuvos kūno kultūros akademija

(Lithuanian Academy of Physical Education)

Sporto g. 6, LT-44221 Kaunas

Lietuva (Lithuania)

Tel +370685 12032

E-mail edita@eik.lt 